\title{
Akuntansi Perbankan Syariah Pada SMK LP3 Istana Jakarta Selatan
}

\author{
Mira Rahmi \\ FEB UPN Veteran Jakarta, Indonesia, mira.upn@gmail.com \\ Toni Priyanto \\ FEB UPN Veteran Jakarta, Indonesia, tonidaffa2002@gmail.com \\ Jenji Gunaedi Argo \\ FEB UPN Veteran Jakarta, Indonesia, jenzargo@yahoo.com
}

\begin{abstract}
Vocational high school (SMK) is designing to set student ready to work after their finish their senior educational level. However, the current curriculum of SMK not yet design for the sharia competency. In reality, lack of knowledge of sharia were exist on students and also the teachers. Huge demand in sharia industry is not an issue for vocational high school due to the lack system and human resources. One of solution that are given by FEB UPN "Veteran" Jakarta team is socialize the sharia knowledge to SMK LP3 ISTANA, Pondok Labu, South Jakarta. The team introduced sharia banking knowledge in order to give insight opportunity for sharia banking industry, the subject given related to accounting simulation on sharia banking transaction. The action taken by The Community Service (PKM) FEB UPN "Veteran" Jakarta, were dedicated to help education community (SMK LP3 ISTANA) gets ready in preparing sharia opportunity as their skill concept for their graduated. Based on the evaluation of the results of PKM activities, the knowledge of the participants (students) SMK about Islamic banking are increase, especially regarding the accounting transactions. Furthermore, there will be a visit program to the Mini's Banking FEB UPNVJ is projected to be implemented.
\end{abstract}

Keywords: Human Resources, Vocational high school, Accounting, Sharia Banking

PENDAHULUAN

\section{Analisis Situasi}

Sumber daya manusia (SDM)
yang berkualitas merupakan kunci
keberhasilan untuk pembangunan suatu
negara. Pengembangan SDM yang memiliki kekuatan spiritual keagamaan,

Available at

http://journal.unj.ac.id/unj/index.php/jpm pengendalian diri, kepribadian, kecerdasan, akhlak yang mulia serta penguasaan keterampilan atau kompetensi menjadi poin-point yang diamanatkan oleh Undang-undang. Oleh karena itu, pendidikan sebagai upaya untuk pengembangan potensi sumber 
daya manusia (SDM) menjadi seseatu yang penting.

\section{Sekolah Menengah Kejuruan} atau yang disebut SMK merupakan bagian dari Sistem Pendidikan Nasional, yang mempunyai peranan penting didalam menyiapkan dan mengembangkan Sumber Daya Manusia (SDM). Sebagai upaya menciptakan tenaga kerja yang terampil, produktif dan siap kerja, pemerintah terus mendorong peningkatan dan pengembangan Sekolah Menengah Kejuruan (SMK) sebagai alternatif pendidikan menengah yang dapat dipilih siswa untuk melanjutkan pendidikannya guna memenuhi kebutuhan berbagai industri untuk memenuhi kebutuhan SDM nya. Keahlian di SMK, khususnya kompetensi keahlian menjadi ujung tombak penciptaan link and match SMK dengan dunia kerja. Perbankan syariah yang merupakan salah pelaku industri dalam dunia usaha saat ini berkembang cukup pesat, sehingga menciptakan peluang permintaan tenaga kerja profesional dalam perbankan syariah yang terus meningkat setiap tahunnya.

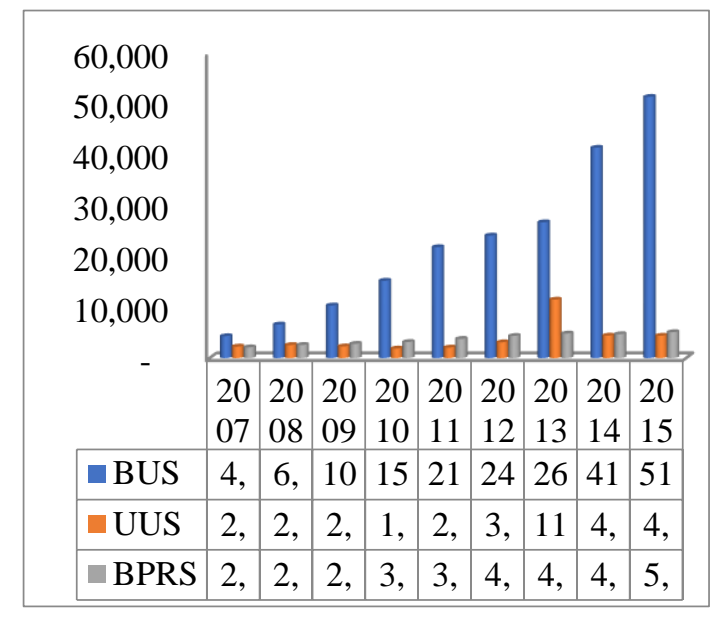

Sumber : Statistik Perbankan Syariah Bank Indonesia - diolah

Gambar 1. Jumlah Pekerja Perbankan Syariah Des 2007 s.d Des 2015

Pesatnya pertumbuhan industri keuangan syariah khususnya perbankan syariah ditandai dengan tercapainya pangsa pasar perbankan syariah di level $5 \%$ pada tahun 2015, keberhasilan ini terlihat dengan semakin pesatnya pertumbuhan aset, jumlah bank dan jumlah kantor perbankan syariah yang tentunya berdampak positif pada peningkatan kebutuhan Sumber Daya Insani (SDI) pada industri perbankan syariah

Pentingnya pengenalan transaksi dan atau perbankan syariah pada SMK merupakan bentuk penciptaan link and match SMK dengan dunia kerja. 
Pengenalan transaksi atau perbankan syariah gencar dilakukan pemerintah dan industri kepada masyarakat tak terkecuali pada dunia pendidikan. Bahkan upaya lembaga pendidikan untuk membuka program studi perbankan syariah juga ikut menjamur baik di level pendidikan tinggi dan menengah.

Daerah Pondok Labu merupakan lingkungan yang berada tidak jauh dari wilayah Universitas Pembangunan Nasional "Veteran" Jakarta, atau tepatnya di dekat RS Prikasih dimana penduduknya sangat beragam khususnya di bidang ekonomi, yang dapat terlihat dari beberapa indikator, diantaranya tempat tinggal, pendapatan maupun pendidikan serta pekerjaannya. Dari segi pendidikan di daerah ini ada beberapa SMK, dimana LP3I merupakan salah satu SMK yang diminati dan siswa-siswi tersebut merupakan asset penerus bangsa sehingga perlu adanya pembinaan yang terarah dalam bidang pengetahuan.

SMK LP3 ISTANA adalah sekolah menegah kejuruan yang berlokasi di Jalan Margasatwa No.12 Pondok Labu Jakarta Selatan. Sekolah

Available at http://journal.unj.ac.id/unj/index.php/jpm ini hadir sejak Mei 2000 yang didirikan dengan tujuan yang sangat mulia, yaitu ingin menciptakan anak-anak bangsa yang tidak mampu secara ekonomi untuk menjadi mandiri, bertaqwa dan bermoral. SMK LP3 ISTANA yang telah mendapatkan akreditasi B memiliki 2 program keahlian, yaitu Akuntansi dan Usaha Perjalanan Wisata. Untuk menunjang aktivitas belajar mengajar terdapat beberapa mata pelajaran kompetensi yang sesuai dengan program keahlian yang diberikan khususnya untuk jurusan akuntansi seperti tersaji pada tabel 1 berikut ini.

Tabel 1. Daftar Mata Pelajaran Kompetensi Akuntansi 


\begin{tabular}{|c|l|}
\hline No & \multicolumn{1}{|c|}{ Mata Pelajaran } \\
\hline 1 & Pengantar Akuntansi \\
\hline 2 & Pengantar Ekonomi dan Bisnis \\
\hline 3 & $\begin{array}{l}\text { Pengantar Administrasi } \\
\text { Perkantoran }\end{array}$ \\
\hline 4 & Etika Profesi \\
\hline 5 & Dasar-dasar Perbankan \\
\hline 6 & Akuntansi Keuangan \\
\hline 7 & Akuntansi Perusahaan Dagang \\
\hline 8 & Akuntansi Perusahaan Manufaktur \\
\hline 9 & Administrasi Pajak \\
\hline 10 & Komputer Akuntansi \\
\hline 11 & $\begin{array}{l}\text { Paket Program } \\
\text { Angka/Spreadsheet }\end{array}$ \\
\hline 12 & Simulasi Digital \\
\hline
\end{tabular}

Sumber : Website SMK LP3 ISTANA diolah

Dalam hal lulusan, sebagaimana ditunjukkan oleh tabel 2 Program Keahlian Akuntansi telah menghasilkan lulusan sebanyak 86 orang sejak tahun 2012 s.d 2016. Dari 86 lulusan sebanyak 64 orang telah bekerja dengan serapan tertinggi pada sektor retail dan sebanyak 22 orang melanjutkan pendidikan tinggi di berbagai universitas khususnya di Jakarta. Dari profile lulusan tersebut terlihat bahwa sekolah cukup mampu menciptakan lulusan yang siap bekerja pada sektor riil, selanjutnya sekolah perlu melakukan berbagai upaya pengembangan kualitas untuk dapat memperluas sektor industri yang dapat menyerap lulusan.

Tabel 2. Profil Lulusan Program Keahlian Akuntansi

\begin{tabular}{|c|c|c|c|c|}
\hline No & $\begin{array}{c}\text { Tahun } \\
\text { Lulus }\end{array}$ & Lulus & Bekerja & Kuliah \\
\hline 1 & 2012 & 21 & 15 & 6 \\
\hline 2 & 2013 & 20 & 16 & 4 \\
\hline 3 & 2014 & 18 & 15 & 3 \\
\hline 4 & 2015 & 10 & 8 & 2 \\
\hline 5 & 2016 & 17 & 10 & 7 \\
\hline & Jumlah & $\mathbf{8 6}$ & $\mathbf{6 4}$ & $\mathbf{2 2}$ \\
\hline
\end{tabular}

Perumusan Masalah

Kesiapan lembaga pendidikan untuk memenuhi lulusan yang kompeten dan siap pakai menjadi keharusan yang tidak terelakkan bagi lembaga pendidikan baik di level pendidikan menengah maupun pendidikan tinggi. Namun demikian terdapat beberapa kendala yang dihadapi lembaga pendidikan khususnya pendidikan kejuruan untuk mewujudkannya diantaranya adalah kemampuan dan kesiapan SMK untuk menyiapkan 
lulusan yang sesuai dengan kebutuhan pasar atau industri.

Saat ini SMK LP3 ISTANA telah memiliki jurusan akuntansi sebagai program keahlian dan dari daftar mata pelajaran kompetesi terlihat telah diberikan beberapa mata pelajaran yang relevan dengan kebutuhan industri seperti Akuntansi Perusahaan Dagang, Akuntansi Perusahaan Manufaktur Administrasi Pajak, Komputer Akuntansi, dan Dasar-dasar Perbankan. Namun dari analisis situasi yang telah diuraikan di atas, peluang lapangan pekerjaan pada industri keuangan dan perbankan syariah demikian besar. Untuk menyiapkan lulusan SMK yang memiliki pengetahuan dan keterampilan akan keuangan dan perbankan syariah dinilai perlu untuk menambahkan mata pelajaran yang bermuatan keuangan dan perbankan syariah baik dalam perspektif konsep dasar maupun perspektif akuntansi. Sehingga diharapkan lulusan SMK LP3 ISTANA memiliki dasar pengetahuan dan keterampilan yang dapat digunakan untuk menghadapi dunia kerja pada industri syariah, maupun bekal untuk melanjutkan ke perguruan tinggi.

Available at http://journal.unj.ac.id/unj/index.php/jpm

\section{Tujuan dan Manfaat}

Program Kemitraan Masyarakat (PKM) ini dilakukan pada SMK LP3 ISTANA dengan target peserta adalah siswa kelas XI dan juga guru. Kegiatan tersebut dimaksudkan untuk memberikan tambahan pengetahuan dan wawasan mengenai konsep dan pelaksanaan praktis perbankan syariah terutama mengenai pencatatan akuntansinya. Tujuannya agar peserta dapat mendapatkan gambaran bahwa pengetahuan akan perbankan syariah sangat dibutuhkan bagi siswa Jurusan Akuntansi untuk menghadapi dunia kerja dan pendidikan lanjutan di Perguruan Tinggi nantinya. Oleh karena itu diharapkan kegiatan ini dapat memberikan masukan bagi pihak sekolah untuk dapat mempertimbangkan memberikan pengetahuan atau pelajaran yang bermuatan keuangan dan perbankan syariah kepada siswa.

\section{Manfaat}

Manfaat atau harapan atas luaran dari kegiatan ini antara lain:

1. Peserta dapat memahami pengertian serta dasar hukum akuntansi syari'ah, serta memahami persamaan dan 
perbedaan antara akuntansi syari'ah dengan akuntansi konvensional.

2. Peserta dapat memahami konsep akuntansi transaksi syariah yang terjadi pada perbankan syariah, seperti transaksi dengan akad: wadiah, mudharabah, murabahah, musyarakah, ijarah, salam, wakalah, kafalah, hawalah, dan lain-lain.

3. Peserta memahami akan Pembukuan Akuntansi secara praktis operasional atas transaksi pada perbankan syariah.

4. Mengenai pemahaman konsep dan pelaksanaan praktis diharapkan peserta memiliki wawasan pengetahuan berbasis praktis yang dapat dijadikan bekal untuk menghadapi dunia kerja pada industri syariah dan melanjutkan pendidikan ke perguruan tinggi.

5. Menjadi dasar untuk pertimbangan manajemen sekolah untuk memberikan mata pelajaran bermuatan keuangan dan perbankan syariah pada program keahlian akuntansi.

\section{KAJIAN TEORITIK}

Pendidikan adalah merupakan sarana pengembangan dan peningkatan kulitas SDM, pemerintah melalui Undang-undang No.20 Tahun 2003 (UU

Available at http://journal.unj.ac.id/unj/index.php/jpm
No.20 Tahun 2003) tentang sistem pendidikan nasional salah satunya menyatakan bahwa "jalur pendidikan adalah wahana yang dilalui peserta didik untuk mengembangkan potensi diri dalam suatu proses pendidikan yang sesuai dengan tujuan pendidikan". Sekolah Menengah Kejuruan atau yang disebut SMK merupakan bagian dari Sistem Pendidikan Nasional. Menurut PP No. 19 Tahun 2005 pasal 16 "standar kompetensi lulusan pada satuan pendidikan menengah kejuruan bertujuan untuk meningkatkan kecerdasan, pengetahuan, kepribadian, ahklak mulia, serta keterampilan untuk hidup mandiri dan mengikuti pendidikan lebih lanjut sesuai dengan kejuruannya". Bagi sekolah kejuruan agar mampu menciptakan tenaga kerja yang kompeten untuk mendukung kebutuhan industri, terdapat beberapa konsep yang perlu dilakukan (Aini, 2010), yaitu efisiensi dan efektifitas menejemen sekolah, peningkatan kompetensi tenaga pengajar, peningkatan hubungan kerjasama dengan industri dan reengineering program keahlian SMK jurusan teknologi industri. Menurut Jatmoko (2013) pengembangan bidang 
studi keahlian, program studi keahlian maupun kompetensi keahlian yang relevan dengan kebutuhan industri merupakan salah satu upaya mengembangkan SMK.

Sedangkan Supriadi (1996:54) mengemukakan bahwa "agar pendidikan dapat memainkan perannya maka harus terkait dengan dunia kerja, artinya lulusan pendidikan semestinya memiliki kemampuan dan keterampilan yang relevan dengan tuntutan dunia kerja. Hanya dengan cara ini, pendidikan mempunyai kontribusi terhadap ekonomi”. Dari pengertian diatas dapat disimpulkan bahwa SMK merupakan pendidikan formal yang menyiapkan dan mencerdaskan peserta didik untuk memiliki kemampuan dan keterampilan sehingga dapat memenuhi kebutuhan/tuntutan dunia usaha/industri sehingga memiliki link and match dengan kebutuhan industri atau berwirausaha. Menurut Slamet dalam Dewi (2013) dengan link and match diharapkan lulusan SMK lebih siap dalam memasuki dunia kerja.

Perbankan syariah yang merupakan salah pelaku industri dalam dunia usaha berkembang cukup pesat saat ini, yang menciptakan peluang permintaan tenaga kerja. Bank syariah dapat diartikan sebagai lembaga keuangan/perbankan yang operasional dan produknya dikembangkan berlandaskan Al-Qur'an dan Hadits Nabi SAW, berbeda dengan bank konvensional pada umunya. Kaidah Akuntansi dalam konsep Syariah Islam dapat didefinisikan sebagai kumpulan dasar-dasar hukum yang baku dan permanen, yang disimpulkan dari sumber-sumber Syariah Islam dan dipergunakan sebagai aturan oleh seorang akuntan dalam pekerjaannya, baik dalam pembukuan, analisis, pengukuran, pemaparan, maupun penjelasan, dan menjadi pijakan dalam menjelaskan suatu kejadian atau peristiwa.

Menurut Toshikabu Hayashi dalam tesisnya yang berjudul "On Islamic Accounting", Akuntansi Barat (Konvensional) memiliki sifat yang dibuat sendiri oleh kaum kapital dengan berpedoman pada filsafat kapitalisme, sedangkan dalam Akuntansi Islam ada konsep Akuntansi yang harus dipatuhi, yaitu hukum Syariah yang berasal dari Tuhan yang bukan ciptaan manusia dan 
Akuntansi Islam sesuai dengan kecenderungan manusia yaitu hanief yang menuntut agar perusahaan juga memiliki etika dan tanggung jawab sosial, bahkan ada pertanggungjawaban di akhirat, dimana setiap orang akan mempertanggungjawabkan tindakannya di hadapan Allah SWT. Tuhan yang memiliki Akuntan sendiri (Rakib dan Atid) yang mencatat semua tindakan manusia bukan saja pada bidang ekonomi, tetapi juga masalah sosial dan pelaksanaan hukum Syariah lainnya.

\section{MATERI DAN METODE}

\section{Kerangka Pemecahan Masalah}

Kerangka pemecahan masalah penelitian ini adalah untuk memberikan tambahan pengetahuan dan keterampilan tentang konsep dan pelaksanaan akuntansi perbankan syariah, yang dapat digunakan untuk menghadapi dunia kerja pada industri syariah khususnya, maupun bekal untuk melanjutkan ke perguruan tinggi. Gambar 2 dibawah ini merupakan tahapan alur kegiatan PKM:

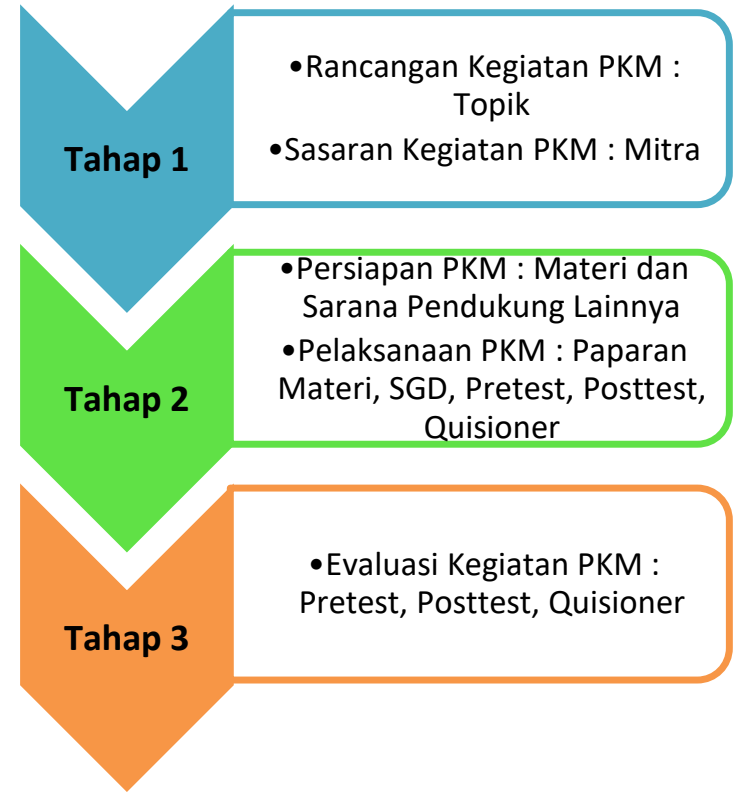

Gambar 2. Alur Kegiatan PKM

Pada gambar 2 alur kegiatan PKM yaitu tahap ke 2, materi yang disampaikan terlebih dahulu mengenai pencatatan akuntansi secara umum yang biasa dipakai di bank konvensional, kemudian dilanjutkan dengan akuntansi perbankan syariah. Akuntansi perbankan syariah pada dasarnya mempunyai tujuan sebagai berikut:

1. Menentukan hak dan kewajiban pihak terkait, termasuk hak dan kewajiban dari transaksi yang belum selesai dan atau kegiatan ekonomi lain, sesuai dengan prinsip syariah yang berlandaskan konsep kejujuran, keadilan, kebijakan, dan kepatuhan terhadap nilai-nilai bisnis islami; 
2. Menyediakan informasi keuangan yang bermanfaat bagi para pemakai laporan dalam pengambilan keputusan; dan

3. Meningkatkan kepatuhan terhadap prinsip syariah dalam semua transaksi dan kegiatan usaha.

Persamaan Akuntansi Pada Bank Syariah:

$$
\begin{gathered}
\text { ASSET }= \\
\text { LIABILITY }+ \text { INVESMENT }+ \text { EQUITY } \\
\text { PROFIT } / \text { LOSS }=(\text { FUNDS REVENUE } \\
- \text { REVENUE } \\
\text { SHARING })+ \text { NON } \\
\text { FUNDS REVENUE }+ \\
\text { EXPENSES }
\end{gathered}
$$

Materi yang disampaikan berikutnya dibagi kedalam 2 (dua) bagian yaitu:

1. Akuntansi penghimpunan dana yaitu wadiah dan mudharabah.

Wadiah adalah berupa titipan barang/aset dari pemilik (muwaddi') kepada pengelola barang/aset (mustawda') untuk melakukan kegiatan penyimpanan dan pengelolaan dari

Available at http://journal.unj.ac.id/unj/index.php/jpm barang/asset sesuai syariah, sehingga tidak dipesyaratkan di awal akad, atau bonus diberikan saat menutup rekening tanpa di persyaratkan diawal.

Mudharabah atau simpanan adalah penanaman dana dari pemilik dana (shahibul maal) kepala pengelola dana (mudharib) untuk melakukan kegiatan usaha tertentuyang sesuai syariah, dengan pembagian hasil usaha antara kedua belah pihak berdasarkan nisbah yang telah disepakati.

2. Akuntansi penyaluran dana dan atau penyediaan jasa yaitu murabahah, salam, istishna', investasi mudharabah, investasi musyarakah, sewa ijarah, dan sewa ijarah muntahiyah bittamlik.

Murabahah adalah jual - beli barang pada harga asal dengan tambahan keuntungan yang disepakati, sehingga penjual harus memberi tahu harga pokok dan berapa keuntungan sebagai tambahannya.

Salam adalah transaksi jual beli dimana barang yang diperjual belikan belum ada dalam kata lain barang harus dipesan namun dengan spesifikasi kuantitas dan kualitas yang jelas. Oleh karena itu barang di serahkan dikemudian hari sedangkan 
pembayarannya dilakukan dimuka secara tunai.

Istishna' adalah transaksi jual beli dimana barang yang diperjual belikan belum ada dalam kata lain barang harus dipesan namun dengan spesifikasi kuantitas dan kualitas yang jelas. Oleh karena itu barang di serahkan dikemudian hari sedangkan pembayarannya dilakukan sesuai kesepakatan bisa dengan bertahap dengan syarat atau ketika barang diterima.

Mudharabah merupakan akad pembiayaan antara bank syariah sebagai shahibul maal dan nasabah sebagai mudharib untuk melaksanakan kegiatan usaha dimana bank syariah memberikan modal sebanyak $100 \%$ dan nasabah menjalankan usahanya. Hasil usaha atas pembiayaan mudharabah akan dibagi antara bank syariah dan nasabah dengan nisbah bagi hasil yang telah disepakati pada saat akad.

$$
\text { Musyarakah atau Syirkah }
$$

merupakan akad kerja sama usaha antara dua pihak atau lebih dalam menjalankan usaha, dimana masing-masing pihak menyertakan modalnya sesuai dengan kesepakatan, dan bagi hasil atas usaha

Available at http://journal.unj.ac.id/unj/index.php/jpm bersama diberikan sesuai dengan kontribusi dana atau sesuai kesepakatan bersama.

Ijarah merupakan kontrak antara bank syariah sebagai pihak yang menyewakan barang dan nasabah sebagai penyewa, dengan menentukan biaya sewa yang disepakati oleh pihak bank dan pihak penyewa. Barang-barang yang dapat disewakan pada umumnya yaitu asset tetap (gedung, mesin dan peralatan, kendaraan, dan asset tetap lainnya).

\section{Realisasi Pemecahan Masalah}

Adapun realisasi pemecahan masalah dalam kegiatan PKM ini adalah:

1. Melakukan audiensi kepada guru, hal ini dilakukan untuk mengetahui tentang program yang telah diberikan sekolah bagi siswa yang terkait tentang akuntansi perbankan syariah;

2. Memberikan pretest kepada para peserta, hal ini dilakukan untuk mengetahui dan mengukur sejauh mana pengetahuan peserta tentang akad dan jenis transaksi yang ada dalam perbankan syariah;

3. Dengan melakukan sosialisasi dalam bentuk ceramah, materi yang 
akan diberikan yaitu mengenai transaksi dengan akad dan pencatatan transaksi perbankan syariah;

4. Small Group Discussion (SGD) yang akan mendiskusikan konsep dan pelaksanaan praktis akuntansi pada perbankan syariah;

5. Memberikan post test berupa simulasi akuntansi syariah kepada peserta, hal ini dilakukan untuk mengetahui tingkat pemahaman peserta terkait dengan materi yang sudah disampaikan, yaitu mengenai pencatatan akuntansi atas transaksi perbankan syariah;

6. Memberikan kuesioner seperti terlihat pada gambar 3 kepada peserta untuk mengetahui apakah pelaksanaan kegiatan tepat sasaran, efektif, dan sesuai dengan kebutuhan serta memberikan manfaat.

Available at

http://journal.unj.ac.id/unj/index.php/jpm

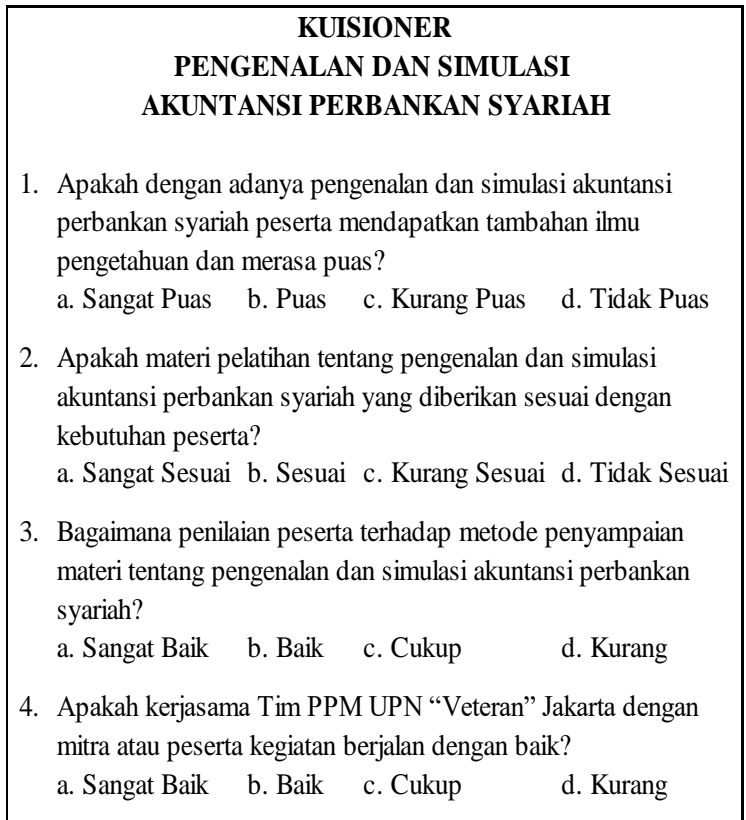

Gambar 3. Quisioner

7. Memberikan rekomendasi kepada pihak sekolah terkait pentingnya diberikan pelajaran yang bermuatan perbankan dan akuntansi syariah untuk memberikan bekal kepada siswa dalam menghadapi dunia kerja dan pendidikan lanjutan di Perguruan Tinggi nantinya.

\section{Khalayak Sasaran dan Metode}

Pengusul melaksanakan kegiatan sosialisasi/ceramah, menyiapkan pretest, posttest, quisioner dan materi ceramah. Sedangkan mitra menyediakan sarana, prasarana dan peserta.

Adapun bentuk luaran yang dihasilkan dalam kegiatan ini adalah: 
1. Meningkatnya pengetahuan peserta tentang perbankan syariah khususnnya mengenai akuntansi perbankan Syariah.

2. Hasil dari pengabdian ini akan diterbitkan di artikel ilmiah.

\section{HASIL DAN PEMBAHASAN}

Rangkaian pelaksanaan kegiatan PPM yang telah dilakukan dari mulai penentuan rancangan dan sasaran kegiatan, persiapan dan pelaksanaan kegiatan, sampai dengan evaluasi kegiatan adalah sebagai berikut:

\section{- Tahap 1: Rancangan dan Sasaran}

\section{Kegiatan PKM}

Hal yang pertama dilakukan adalah menentukan rancangan dan sasaran kegiatan, ini dilakukan mulai bulan Januari 2017 rancangan kegiatannya yaitu berupa pengenalan akuntansi perbankan syariah dan sasarannya yaitu sekolah kejuruan SMK LP3 ISTANA Jakarta Selatan. Koordinasi dengan SMK LP3 ISTANA selaku mitra PPM dilakukan sekitar bulan Januari-Februari 2017 sebelum proposal PPM ini diusulkan, agar terlebih dahulu didapatkan kesesuaian

Available at

http://journal.unj.ac.id/unj/index.php/jpm antara rancangan kegiatan PPM dengan kebutuhan mitra sebagai sasaran PPM.

Pada tahap ini juga dilakukan koordinasi untuk mendapatkan izin pelaksanaan kegiatan dari mitra, dan izin telah diberikan dengan diterbitkannya Surat Kesediaan Mitra pada tanggal 19 Februari 2017. Selanjutnya ditentukan waktu pelaksanaan yaitu pada Agustus 2017, yang akan dilaksanakan selama 2 hari.

\section{- Tahap 2: Persiapan dan}

\section{Pelaksanaan PPM}

Persiapan pelaksanaan kegiatan dimulai Mei 2017, persiapan yang dilakukan yaitu berupa perumusan materi kegiatan, penyusunan materi presentasi (PPT), dan pengadaan sarana pendukung. Sedangkan kegiatannya dilaksanakan pada tanggal 6 dan 7 September 2017 di Gedung SMK LP3 ISTANA Jl. Raya Margasatwa, Pondok Labu Jakarta Selatan.

Materi yang disampaikan di hari pertama yaitu mengani akuntansi atas transaksi penghimpunan dana yaitu wadiah dan mudharabah, dan di hari kedua yaitu mengenai akuntansi atas transaksi penyaluran dana dan atau penyediaan jasa yaitu murabahah, 
salam, istishna', investasi mudharabah, investasi musyarakah, sewa ijarah, dan sewa ijarah muntahiyah bittamlik.

Kegiatan dilakukan dalam bentuk paparan materi dan juga dilakukan small group discussion (SGD) yang dibagi dalam 4 sesi. Sesi pertama yaitu mengisi pretest dan kemudian dilanjutkan dengan paparan materi, sesi kedua yaitu SGD, sesi ketiga yaitu posttest dalam bentuk simulasi akuntansi dan sesi keempat yaitu sesi tanya jawab serta mengisi quisioner.

\section{- Tahap 3: Evaluasi Kegiatan PPM}

\section{Evaluasi kegiatan PPM selain dinilai dari hasil posttest yang dibandingkan dengan hasil pretest dan quisioner juga dari pengamatan langsung tim pelaksana PPM selama megadakan kegiatan tersebut. Parameter pengukuran pencapaian taget luaran tersebut dibagi menjadi dua jenis, yang pertama pretest dan posttest, dan yang kedua melalui kuisioner yang diberikan pada akhir kegiatan.}

\section{a) Evaluasi Pretest dan Posttest}

Dari evaluasi pretest dapat diketahui tingkat pemahaman peserta terkait dengan materi yang akan disampaikan, yaitu mengenai akad

Available at

http://journal.unj.ac.id/unj/index.php/jpm dan jenis transaksi yang ada dalam perbankan syariah. Soal pretest terdiri dari 10 soal pilihan berganda dengan nilai tertinggi sebesar 100 dan terendah 0 .

Sedangkan evaluasi posttest untuk mengetahui tingkat pemahaman peserta terkait dengan materi yang sudah disampaikan, yaitu mengenai pencatatan akuntansi atas transaksi perbankan syariah. Soal posttest berupa simulasi akuntansi yaitu kertas kerja atas sejumlah transaksi penghimpunan dana yaitu wadiah dan mudharabah, serta transaksi penyaluran dana dan atau penyediaan jasa yaitu murabahah, salam, istishna, investasi mudharabah, investasi musyarakah, sewa ijarah, dan sewa ijarah muntahiyah bittamlik.

Soal pretest terdiri dari 10 soal pilihan berganda dengan nilai tertinggi sebesar 100 dan terendah 0 , indikator pencapaian target yaitu nilai rata-rata $>70$ artinya peserta sudah dapat menerima materi akuntansi perbankan syariah karena sudah paham mengenai akad dan jenis transaksinya. Untuk posttest indikator pencapaian target 
yaitu rata-rata nilai $>80$, soal berupa simulasi akuntansi yaitu kertas kerja yang terdiri dari 7 soal, 3 soal atas transaksi penghimpunan dana dengan bobot nilai 40, dan 4 soal atas transaksi penyaluran dana dan atau penyediaan jasa dengan bobot nilai 60 , dengan total bobot nilai 100.

Dari hasil pretest diperoleh data rata-rata nilai test yaitu sebesar 78 diatas nilai target capaian yaitu sebesar 70 yang artinya peserta sudah paham mengenai akad dan jenis transaksi yang ada dalam perbankan syariah. Persentase terbesar adalah peserta yang mendapatkan nilai 70-80 yaitu sebesar $58 \%$, yang artinya peserta sudah paham mengenai akad dan jenis transaksi yang ada dalam perbankan syariah, tetapi sepertinya belum mengetahui mengenai pencatatan akuntansi atas transaksi perbankan syariah tersebut.

Tabel 3. Hasil Pretest dan Postest

Peserta

\begin{tabular}{|c|c|c|c|c|}
\hline \multirow{2}{*}{$\begin{array}{c}\text { Renta } \\
\text { ng }\end{array}$} & \multicolumn{2}{|c|}{ Pretest } & \multicolumn{2}{c|}{ Postest } \\
\cline { 2 - 5 } Nilai & $\begin{array}{c}\text { Jml } \\
\text { Peser } \\
\text { ta }\end{array}$ & & Jml & $\%$ \\
& & $\begin{array}{c}\text { Pesert } \\
\text { a }\end{array}$ & \\
\hline$<70$ & 3 & $13 \%$ & 2 & $8 \%$ \\
\hline $70-80$ & 14 & $58 \%$ & 4 & $17 \%$ \\
\hline
\end{tabular}

\begin{tabular}{|c|c|c|c|c|}
\hline $80-100$ & 7 & $29 \%$ & 18 & $75 \%$ \\
\hline & & Nilai & & Nilai \\
& & Rata & & Rata \\
& & -rata & & -rata \\
\hline & 24 & 78 & 24 & 85 \\
\hline
\end{tabular}

Sedangkan dari hasil posttest diketahui rata-rata nilai adalah sebesar 85 yang berarti diatas ratarata target capaian yaitu sebesar 80 , dapat dikatakan peserta sudah paham akan akad, jenis transaksi dan juga pencatatan akuntansi atas transaksi perbankan syariah. Terlihat juga bahwa nilai rata-rata peserta pretest sebesar 78 dan pada saat posttest naik menjadi 85, ini menjadi juga indikator bahwa pemahaman peserta tentang perbankan syariah meningkat.

\section{b) Evaluasi Qusioner}

Evaluasi quisioner terdiri dari empat indikator sebagai berikut:

\section{Evaluasi Kepuasan Peserta PKM}

Tingkat kepuasan peserta adalah indikator utama untuk melihat keberhasilan pelaksanaan suatu kegiatan. Jika respon yang ditunjukkan peserta pada kategori 
positif yaitu sangat puas atau puas, maka dapat diartikan bahwa kegiatan tersebut punya kesan yang baik bagi peserta, seperti terlihat pada gambar berikut ini:

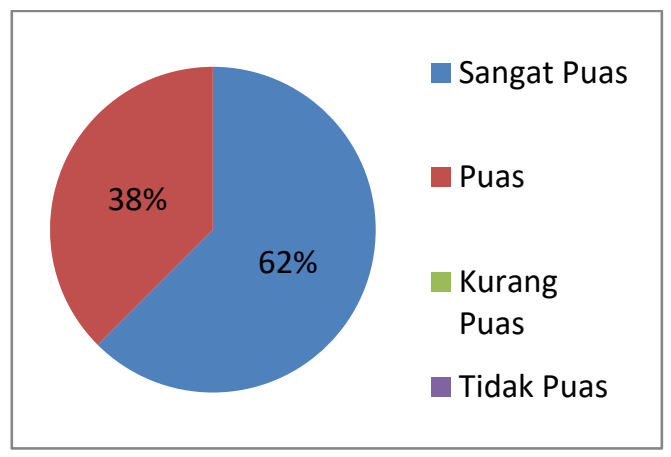

Gambar 4. Respon Peserta PKM

Dari data di atas $62 \%$ peserta PKM sangat puas dan $38 \%$ peserta puas atas pelatihan yang diberikan. Hasil ini menunjukkan peserta memberikan respon positif atas kegiatan yang dilakukan dan diharapkan ini dapat meningkatkan pengetahuan siswa tentang perbankan syariah.

\section{Evaluasi Kesesuaian Kegiatan}

\section{dengan Kebutuhan Mitra}

Indikator kedua yang di ukur adalah kesesuaian kegiatan PKM dengan kebutuhan mitra atau sasaran kegiatan. Tim PKM UPNVJ berharap materi pelatihan yang diberikan dapat memberikan informasi mengenai akuntansi perbankan syariah yang selama ini belum pernah diberikan dalam kurikulum atau pelajaran sekolah, artinya ada kesesuaian antara kebutuhan mitra dengan kegiatan PKM.

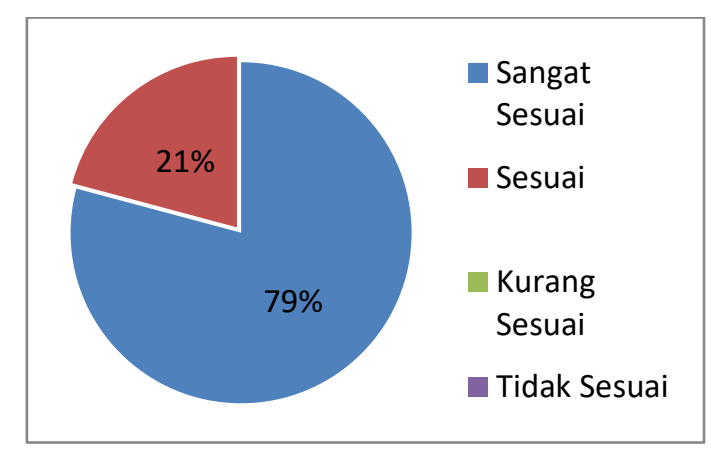

Gambar 5. Respon Kesesuaian

Kebutuhan.

Dari data di atas persentase respon peserta PKM yang menganggap pelatihan sangat sesuai dengan kebutuhan sebanyak $79 \%$ dan persentase respon yang menganggap sesuai sebanyak $21 \%$. Hasil ini menunjukkan bahwa materi yang disampaikan dalam pelatihan relevan dengan bidang ilmu yang dipelajari disekolah, artinya kegiatan PKM tepat sasaran, sesuai dengan kebutuhan, 
dan memberikan manfaat bagi mitra.

\section{Evaluasi Metode Penyampaian}

\section{Materi}

Indikator berikutnya adalah mengukur efektifitas metode yang digunakan dalam penyampaian materi pelatihan. Metode yang digunakan adalah melalui metode ceramah dan simulasi transaksi akuntansi yang diselingi dengan diskusi, tanya jawab, serta penyampaian contoh atau pengalaman-pengalaman praktis dari penyaji.

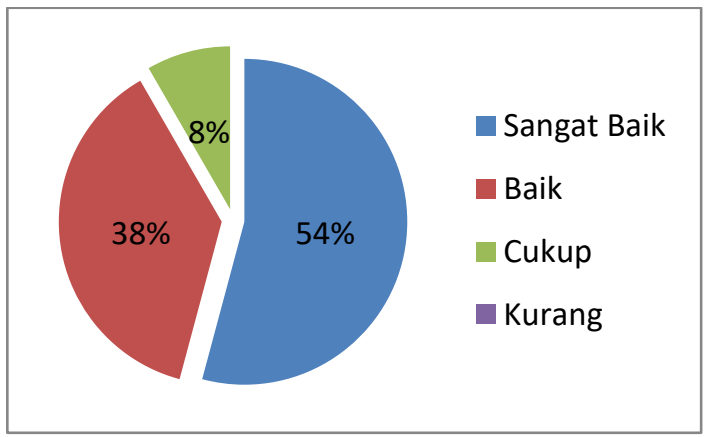

Gambar 6. Metode Penyampain Materi

Hasil tersebut menunjukkan bahwa pemahaman peserta terhadap materi tentang akuntansi perbankan syariah sangat baik sebesar 54\%, pemahaman baik sebesar 38\%, dan yang merasa cukup sebesar $8 \%$. Ini menjadi motivasi bagi pelaksana PKM untuk terus berupaya meningkatan metode penyampaian materi yang lebih efektif dan tepat sasaran.

\section{Evaluasi Kerjasama Tim PKM}

Indikator terakhir yang diukur adalah efektifitas kerjasama Tim PKM dalam pelaksanaan kegiatan pelatihan, hal ini dilakukan guna mengukur apakah tim mampu melaksanakan kegiatan secara efektif. Dari data peserta menilai kerjasama Tim PKM dalam melaksanakan kegiatan sangat baik sebesar 46\%, baik sebesar 33\%, dan cukup sebesar $21 \%$. Hasil ini menunjukkan bahwa pelaksanaan kegiatan yang dilakukan oleh Tim PKM masih perlu ditingkatkan.

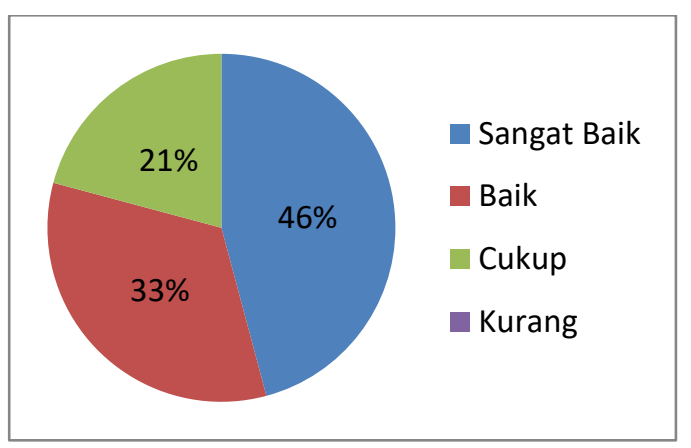

Gambar 7. Kerjasama Tim

Evaluasi kuisioner adalah untuk mengetahui apakah pelaksanaan kegiatan tepat sasaran, efektif, dan sesuai dengan 
kebutuhan serta memberikan manfaat. Berikut tabel indikator hasil kuisioner peserta:

Tabel 4. Hasil Kuisioner Peserta

\begin{tabular}{|c|c|c|c|c|c|c|c|c|c|c|c|}
\hline \multirow[b]{2}{*}{$\begin{array}{l}\mathbf{N} \\
\mathbf{0}\end{array}$} & \multirow[b]{2}{*}{ 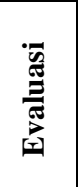 } & \multicolumn{2}{|c|}{1} & \multicolumn{2}{|c|}{2} & \multicolumn{2}{|c|}{3} & \multicolumn{2}{|c|}{4} & \multicolumn{2}{|c|}{ Total } \\
\hline & & : & $\%$ & 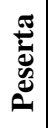 & $\%$ & 불 & $\%$ & 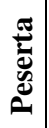 & $\%$ & 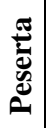 & $\%$ \\
\hline 1 & 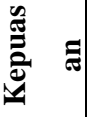 & $\begin{array}{l}1 \\
5\end{array}$ & $\begin{array}{l}62 \\
\%\end{array}$ & 9 & $\begin{array}{l}38 \\
\%\end{array}$ & - & & - & - & $\begin{array}{l}2 \\
4\end{array}$ & $\begin{array}{c}100 \\
\%\end{array}$ \\
\hline & 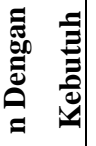 & $\begin{array}{l}1 \\
9\end{array}$ & $\begin{array}{l}38 \\
\%\end{array}$ & 5 & $\begin{array}{l}62 \\
\%\end{array}$ & - & - & - & - & $\begin{array}{l}2 \\
4\end{array}$ & $\begin{array}{c}100 \\
\%\end{array}$ \\
\hline 3 & 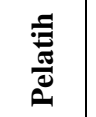 & $\begin{array}{l}1 \\
3\end{array}$ & $\begin{array}{l}54 \\
\%\end{array}$ & 9 & $\begin{array}{l}38 \\
\%\end{array}$ & 2 & $\begin{array}{l}8 \\
\%\end{array}$ & - & - & $\begin{array}{l}2 \\
4\end{array}$ & $\begin{array}{c}100 \\
\%\end{array}$ \\
\hline 4 & 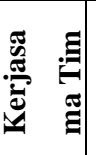 & $\begin{array}{l}1 \\
1\end{array}$ & $\begin{array}{l}46 \\
\%\end{array}$ & 8 & $\begin{array}{l}33 \\
\%\end{array}$ & 5 & $\begin{array}{l}2 \\
1 \\
\%\end{array}$ & - & - & $\begin{array}{l}2 \\
4\end{array}$ & $\begin{array}{c}100 \\
\%\end{array}$ \\
\hline
\end{tabular}

\section{Catatan:}

\section{Sangat Puas/Sangat Sesuai/Sangat Baik}

2. Puas/ Sesuai/ Baik

3. Kurang Puas/Kurang Sesuai/Cukup

4. Tidak Puas/Tidak Sesuai/Kurang

\section{KESIMPULAN DAN SARAN}

\section{Kesimpulan}

Materi akuntansi perbankan syariah dijadikan sebagai topik oleh tim Program Kemitraan Masyarakat (PKM) Fakultas Ekonomi dan Bisnis Universitas Pembangunan "Veteran" Jakarta (FEB UPNVJ) karena dinilai adanya market demand untuk perbankan syariah, tidak terkecuali bagi lulusan sekolah menengah. SMK dipilih karena berdasarkan undang-undang lembaga pendidikan ini bertugas untuk menyiapkan tenaga kerja yang kompeten dan siap pakai, sehingga dinilai perlu untuk memberikan pengetahuan yang relevan dengan kebutuhan industri. Program kemitraan dilakukan dalam bentuk edukasi dan sosialisasi tentang Akuntansi Perbankan Syariah yang diharapkan dapat memberikan alternatif solusi bagi sekolah menengah untuk menyiapkan lulusannya sehingga memiliki link and match dengan kebutuhan industri. Pemilihan SMK LP3 ISTANA Pondok Labu Jakarta Selatan sebagai mitra PKM bertujuan agar keberadaan UPNVJ dapat dirasakan fungsi dan perannya bagi lingkungan dan masyarakat sekitar.

Berdasarkan hasil kegiatan diketahui adanya peningkatan pengetahuan peserta (siswa) SMK tentang perbankan syariah, khususnya mengenai akad, jenis transaksi dan juga pencatatan akuntansi atas transaksi perbankan syariah. Ini artinya capaian 
luaran dari kegiatan PKM tercapai, dapat dilihat bahwa nilai rata-rata peserta pretest sebesar 78 dan pada saat posttest naik menjadi 85, dan komposisi peserta yang nilainya mencapai target capaian 80 mencapai $75 \%$. Sedangkan dari sisi pelaksanaan kegiatan yaitu, kepuasan peserta atas penyelenggaran kegiatan, kesesuaian materi dengan kebutuhan peserta, materi penyampaian materi, dan kerjasama tim, secara keseluruhan baik. Dari hasil kuisioner yang disebar $62 \%$ peserta merasa sangat puas atas penyelenggaraan kegiatan, $62 \%$ peserta menyatakan materi yang diberikan sesuai atau relevan dengan kebutuhan yang diinginkan, 54\% peserta berpendapat metode pelatihan yang diberikan sangat baik, dan $46 \%$ peserta menyatakan kerjasama tim PKM sangat baik.

\section{Saran}

Sebagai tindak lanjut dari kegiatan di atas terdapat beberapa saran untuk kegiatan yang dapat diproyeksikan untuk dilaksanakan, diantaranya yaitu program kunjungan studi siswa SMK pada Laboratorium Praktik Bank Mini FEB UPNVJ, pendampingan penyusunan kurikulum perbankan syariah sebagai salah satu mata pelajaran vokasi yang akan diberikan dan pelatihan yang akan diberikan pada guru-guru untuk menambah dan meningkatkan kompetensi.

\section{DAFTAR PUSTAKA}

Aini, Q. 2010. Konsep Pengembangan Sekolah Menengah Kejuruan (SMK) Berbasis Industri di Kabupaten Sidoarjo. Tesis (tidak dipublikasikan): Institut Teknologi Surabaya.

[BI] Bank Indonesia. 2007 - 2015. Berbagai tahun. Statistik Perbankan Syariah. Direktorat Perizinan dan Informasi Perbankan BI. [internet].[diakses pada tanggal 15 November 2016]. Tersedia pada: http:/www.bi.go.id.

Dewi, I.P. 2013. Hubungan Bimbingan Karir dan Pengalaman Praktik Kerja Industri (Prakerin) dengan Kesiapan Kerja di Bidang Komputer dan Jaringan Siswa SMK Kelas XII Kompetensi Keahlian Teknik Komputer dan Jaringan di Kota Solo. Tesis. Padang: Universitas Negeri Padang.

Jatmoko, D. 2013. Relevansi Kurikulum SMK Kompetensi Keahlian Teknik Kendaraan Ringan terhadap Kebutuhan Dunia Industri di Kabupaten Sleman. Jurnal Pendidikan Vokasi, 3 (1), hlm. 1-13. Kompasiana.Com. 2015. Tuntutan Industri Perbankan Syariah Terhadap Dunia Pendidikan Indonesia. [internet].[diakses pada 
tanggal 10 Januari 2017]. Tersedia pada: http:/www.kompasiana.com.

Sudira, P. 2014. Konsep dan Praksis Pendidikan Hindu Berbasis Tri Hita Kara na PS IHDN Denpasar. [internet].[diakses pada tanggal 10 Januari 2017].

Undang-Undang No.20 Tahun 2003 Tentang Sistem Pendidikan Nasional. [internet].[diakses pada tanggal 10 Januari 2017]. Tersedia pada: http:/www.
sindikker.dikti.go.id/dok/UU/UU202003-Sisdiknas.pdf.

Peraturan Pemerintah (PP) No. 29 Tahun 1990. [internet]. [diakses pada tanggal 10 Januari 2017]. www.peraturan.go.id/pp/nomor-29tahun-1990.

Yaya, Rizal dan Martawireja, Abdurahim, Ahim.2016. Akuntansi Perbankan Syariah: Teori dan Praktik Kontemporer. Jakarta: Salemba Empat. 